Scotland, and in the light of these comparative costs, the North of Scotland Board would decide whether to make the necessary formal inquiries into the hydro-electric schemes. A subordinate recommendation of the Mackenzie Committee was that special assistance should be provided to enable rural electrification in the north of Scotland to be speeded up and to link the islands with the mainland by submarine cable. Mr. Noble said that the North of Scotland Board considered that most of these cables would be needed only when the existing Diesel generating stations on the main islands had to be renewed, but had drawn up a programme for accelerating the present rate at which consumers in the more remote areas could be given supplies.

\section{The Deer Bill}

IN moving the Second Reading of the Decr Bill in the House of Lords on June 28, Viscount Massereene and Ferrard pointed out that the reasons for the Bill were not entirely the same as those which led to the Deer (Scotland) Act, 1959, which followed the report of the Scott-Henderson Committee on cruelty to wild animals, although the clauses dealing with the avoidance of unnecessary cruelty to deer were essentially the same as the corresponding sections of the Scottish Act, but confined to English as opposed to Scottish law. There had been a great increase in the deer population of England and Wales following the increased acreage of timber, now reaching 600,000 acres, and this had altered the pattern of wild-life, while there had also been an increase in arable land. Further, especially in the past fifteen years, the number of weapons in private hands had greatly increased, and while motor-cars had made the countryside more accessible there was still no proper legislation in force to protect deer. Among those who had contributed to the preparation of the Bill besides its sponsors, the British Field Sports Society, Viscount Massereene mentioned the Forestry Commission, the Nature Conservancy, the Council for Nature and the Fauna Preservation Society. Clause 1 dealt with close seasons and provided a close season for stags and bucks from May 1 until July 31 , but no close season was provided for the roebuck, and Viscount Massereene explained that the shorter season than that provided under the Scottish Act was due to the difference in habitat. He also pointed out that under Sub-sections of this Clause the Secretary of State was authorized to amend this Schedule by Order by the addition of any species not mentioned in that Schedule. This would enable other species of wild deer, such as the muntjac and the Chinese water deer, which appeared to be becoming indigenous, to be included. This Clause was the subject of some discussion in a debate in which the Bill was generally welcomed, and Lord Dowding and other speakers advocated that the close season should be advaneed to February. Clause 2 empowers the Nature Conservancy to license such prohibited articles as stupefying drugs or muscle-relaxing agents with the object of taking deer alive for scientific or educational purposes. Controversy centred chicfly on the weapons Clause and was concerned essentially with the tochnicalities of prohibited weapons, both rifles and shot guns. The Bill was committed to a Committee of the whole House.

\section{The National Ports Council}

In moving a resolution in the House of Commons on July 10, welcoming the Government's statement of March 6 , 1963, on the report of the Rochdale Committee of Inquiry into the Major Ports of Great Britain, the Minister of Transport, Mr. E. Marples, said that tho Government fully shared the view expressed in the report as to the need for more research, both technical and operational, but no final conclusion had been reached as to the kind of studies needed and how they should be made. The first need was reconnaissance to supply a complete picture of the technical and operational research already in progress and how it was being conducted. The Lord President of the Council, after consultation with Lord Rochdale and the Minister of Transport, had arranged for such an investigation to be made, and $\mathbf{M r}$. Marples said that he would expect to receive advice from the National Ports Council on the need for economic research on particular problems. On July 9, Mr. Marples, in a written answer, gave the following names of those who had agreed to serve under the chairmanship of Lord Rochdale on the National Ports Council: Mr. E. D. Arney, J. H. Joyce, Ian W. Macdonald, Sir Eric Millburn, D. M. Robinson, E. G. Whitaker and L. T. Wright.

\section{Expenditure on the Commonwealth Education Scheme}

In a written answer in the House of Commons on July 9, the Secretary for Technical Co-operation, Mr. R. Carr, stated that expenditure on the Commonwealth Education Scheme, for which the Government had undertaken to make available up to $£ 6$ million during the five years ending in 1965, included provision for the supply of teachers, for which purpose about $£ 1$ million would be used, and so far nearly $£ 700,000$ had been committed.

The Royal College of Science and Technology, Glasgow

The annual report of the Royal College of Science and Technology, Glasgow, for the one hundred and sixty-sixth session, 1961-62, records a total of 1,997 full-time students, together with 1,203 part-time day and 1,343 evening students (Pp. 89. Glasgow: The Royal College of Science and Technology, 1963). The associateship of the College was conferred on 294 students, of whom 28 were in chemistry, 19 in metallurgy, 48 in civil, 102 in mechanical, 11 in chemical and 41 in electrical engineering. The titles of theses approved for the award of the associateship are listed and there are also lists of recent publications by members of the College and of industrial research reports issued during the year. Twenty-five members of the College obtained the degree of Ph.D. of the University of Glasgow and three the degree of M.Sc. 31 diplomas of membership for postgraduate study were awarded; the titles of theses for all these degrees and awards are also listed. Brief particulars of research in progress are included under the several departmental roports, but a full record is given in the Research Report for the Session 1961 62 , which is published separately and also includes lists of the more important publications and of the titles of theses approved for higher degrees; these lists of publications are annotated (Pp. 43+4 plates. Glasgow: The Royal College of Seience and Technology, 1963). A research group in elasticity has been set up in the Department of Mathematics, and sponsored industrial research for the South of Scotland Electricity Board, the British Shipbuilding Research Association, the Ministry of Aviation and the Cold Rolled Sections A.ssociation continued in the Department of Mechanical, Civil and Chemical Engineering, while work also continued on traffic engineering with reference to the traffic problems in Glasgow.

\section{The British Hydromechanics Research Association}

THE fifteenth annual report of the British Hydromechanics Research Association, covering the year October 1961--September 1962, refers to exploration of the possibility of a closer link with an academic or research institution in a related field, and plans for expanding the laboratory (Pp. 40. Harlow: The British Hydromechanics Research Association, 1963). Research on centrifugal pumps included a study of the axial thrusts that act on some pump impellers and the behaviour of balancing vanes attached to the impeller or to the front-side wall of the pump casing. Low-pressure work on seals and glands is concentrated on elucidating the nature of the interfacial fluid film and the mechanisms involved in pressure generation within this film. Considerable pro- 